\title{
The Correlation between Teacher Professional Competence and Natural Science Learning Achievement in Elementary School
}

I Ketut Ngurah Ardiawan

STAHN Mpu Kuturan Singaraja, Bali, Indonesia Email : ngurahardiawan90@gmail.com

(Received: October-2017; Reviewed: October-2017; Accepted: November-2017; Published: Desember-2017)

(C2017 -EST Graduate Program Universitas Negeri Makassar. This is an article with open access under license CC BY-NC-4.0 (https://creativecommons.org/licenses/by-nc/4.0/ ).

\begin{abstract}
This present study aims at investigating the correlation between teachers' professional competence and natural science learning achievement in elementary schools in Buleleng regency. The population in this study are all sixth grade teachers, which it is further narrowed down to 30 teachers as the sample. In order to gather the data, the researcher employs questionnaire regarding teacher professional competence and document study toward students' achievement on national examination in academic year 2016/2017. Further, ex post facto is chosen as the design of the study. Meanwhile, the data are analysed through correlation analysis with assistance of SPSS 16 software. Based on the analysis, it was obtained that the correlation between teacher professional competence and the learning achievement on natural science subject is in the interval of 0.40-0.59 with correlation coefficient at rho=0.506. This means there is a significant correlation between teacher professional competence and students' learning achievement on natural science in national examination in academic year 2016/2017 $\left(t_{\text {count }}=3.103>t_{\text {table }}=2.048\right.$ with significance level at $\alpha=0,05$ and coefficient of determination at $0.2560(25.60 \%)$
\end{abstract}

Keywords: Natural Science; Learning Achievement; Teacher Professionalism; Elementary School

\section{INTRODUCTION}

As stated in the Indonesia National Standard of Education, teachers who are equipped with four major competences play a key role in the success of an instructional process. The urgency of creating professional teachers has increased in this past few years, as teachers are demanded to improve their own quality. Nevertheless, teachers are considered as means to produce highly qualified human sources that are able to put all their efforts toward development of education (Koksal, 2013; Hakim, 2015). This is in line with Trilling and Fadel (2009) who argue that learning in the 21 st century needs teachers with high qualification, skills, creativity, critical thinking, communicative competence, and collaboration. In addition, teachers also need to be updated to the latest materials as it is dynamically changed. The need to move forward is not only on professional activities, but also on improving somebody's academic level (Drovnikov et al., 2016).

Teachers are required to have the ability to teach and role professionally as well as multifunction in creating an effective learning atmosphere. Thus, professional competence is one of the basic skills that a teacher must have (Sugiharti, 2016). Professional teachers are basically determined by their attitude, willingness and intellectual abilities (Mudiono, 2016). Moreover, the teacher is one of the 
factors in the determinant of success in education efforts.

Since students' learning achievement is the benchmark of students' success in learning, an evaluation regarding the delivered materials is necessary. Generally, the ministry of education in Indonesia has pointed national examination as one of the means to measure students' achievement in school. Aside from determining how effective the instructional process in schools is, implementing national exams also means to determine the degree of teachers' professionalism in their area of interest and how it contributes to improve their teaching strategy (Hakim, 2015).

Based on the aforementioned explanation, Kunter as cited in Bertchy et al. (2013) recommends that this professional competence is needed for teachers to conduct an effective instructional strategy. In addition, professional competence also encourages students to actively participate in the sustainability in education. Accordingly, based to the study conducted by Ilanlou and Zand (2011) which entitled "professional competencies of teachers and the qualitative evaluation", they find out that there is a high correlation between teacher professional competence and their perspective in qualitative evaluation.

Another study related to this topic is also conducted by Kordestani et al. (2014) which entitled "The Study of Elementary School teachers' Professional Competencies and Comparing it with International Standards". This study aims to investigate teachers' professional competence and compare it to the international standard. A descriptive survey design is employed in this study. This study results in revealing that primary school teachers have the seven expected components of professional competence. These components cover instructional design, learning space, learning achievement and its management, communication, in collaboration with parents, society, organisations or school partners, selfreview and evaluation on the academic capacity.
Those studies prove that teacher professionalism has been becoming imperative and inseparable parts of teachers in improving the instructional quality. In other words, these two things have a mutual relationship or can be called as interaction in instructional process. Taking into account of the aforementioned explanation, this article focuses on investigation the correlation between teacher professional competence and students learning achievement on natural science based on the result in national examination.

\section{METHOD}

This present study utilizes ex post facto design. The data in this study are analysed through correlation analysis with the assistance of SPSS 16. An ex post facto study is an approach to investigate the research subjects without giving any treatments to the variables (Dantes, 2012). In order to gather the data, the researcher directly enters the field of the study and searching for the documentation of the national examination in 2016/2017. This research was conducted from May-July 2017 in Buleleng regency. From the sampling, there were 30 primary school teachers from different schools who are selected as the sample of the study.

The data are gathered through some instruments. There are two instruments used in this study, they are questionnaire and documentation. For teacher professional competence, questionnaire with 25 questions are employed. On the other hand, the data for students' achievement in national examination are gathered from students result in national exams in 2017 released by the education authorities in Buleleng regency.

Further, in order to measure whether the quality of the variable is high or low, the mean score of each variable is converted by referring to the ideal mean (Mi) and ideal standard deviation (SDI). The scale is presented as follows.

Table 1. Criteria of Ideal Mean (Mi) and Ideal Standard Deviation (SDI)

\begin{tabular}{l|l}
\hline Score & Category \\
\hline $\mathrm{M}_{\mathrm{i}}+1,5 \mathrm{SD}_{\mathrm{i}} \leq M \leq \mathrm{M}_{\mathrm{i}}+3,0 \mathrm{SD}_{\mathrm{i}}$ & Very High \\
\hline $\mathrm{M}_{\mathrm{i}}+0,5 \mathrm{SDi} \leq M<\mathrm{Mi}+1,5 \mathrm{SD}_{\mathrm{i}}$ & High \\
\hline $\mathrm{M}_{\mathrm{i}}-0,5 \mathrm{SDi} \leq M<\mathrm{Mi}+0,5 \mathrm{SD}_{\mathrm{i}}$ & Moderate \\
\hline
\end{tabular}




\begin{tabular}{c|l}
\hline $\mathrm{M}_{\mathrm{i}}-1,5 \mathrm{SD}_{\mathrm{i}} \leq M<\mathrm{M}_{\mathrm{i}}-0,5 \mathrm{SD}_{\mathrm{i}}$ & Low \\
\hline $\mathrm{M}_{\mathrm{i}}-3,0 \mathrm{SD}_{\mathrm{i}} \leq M<\mathrm{M}_{\mathrm{i}}-1,5 \mathrm{SD}_{\mathrm{i}}$ & Very Low \\
${$\cline { 2 - 2 }$} }$ & $\begin{array}{l}\text { students mean score from the national } \\
\text { examination on natural science subject and } \\
\text { teacher professional competence score as they } \\
\text { are presented in Table } 2 .\end{array}$ \\
This study reveals some findings in
\end{tabular}
students' achievement. The first finding is about

Table 2. Teacher Professional Competence Score and Students' Mean Score in National Examination on Natural Science Subject

\begin{tabular}{llll}
\hline No & Schools & $\begin{array}{l}\text { Prof. } \\
\text { Competence } \\
\text { score }\end{array}$ & $\begin{array}{l}\text { Students' } \\
\text { mean } \\
\text { on } \\
\text { science }\end{array}$ \\
\hline natural \\
\hline 1 & SD LAB UNDIKSHA SGR & 87 & 92,86 \\
\hline 2 & SD MUTIARA & 84 & 69,95 \\
\hline 3 & SD NO. 1 KAMPUNG BARU & 86 & 76,12 \\
\hline 4 & SD NO. 2 KAMPUNG BARU & 83 & 83,19 \\
\hline 5 & SD NO. 3 KAMPUNG BARU & 78 & 71,46 \\
\hline 6 & SD NO. 4 KAMPUNG BARU & 86 & 91,89 \\
\hline 7 & SD NO. 5 KAMPUNG BARU & 90 & 87,64 \\
\hline 8 & SD NO. 7 KAMPUNG BARU & 84 & 75,79 \\
\hline 9 & SD NO. 1 BANJAR BALI & 65 & 75,45 \\
\hline 10 & SD NO. 2 BANJAR BALI & 88 & 87,25 \\
\hline 11 & SD NO. 1 KAMPUNG & 76 & \\
& KAJANAN & & 58,75 \\
\hline 12 & SD NO. 1 ASTINA & 88 & 81,23 \\
\hline 13 & SD NO. 1 BANYUNING & 90 & 78,78 \\
\hline 14 & SD NO. 3 BANYUNING & 84 & 60,25 \\
\hline 15 & SD NO. 4 BANYUNING & 86 & 70,83 \\
\hline 16 & SD NO. 7 BANYUNING & 83 & 83,38 \\
\hline 17 & SD NO. 1 PAKET AGUNG & 90 & 87,16 \\
\hline 18 & SD NO. 2 PAKET AGUNG & 88 & 82,38 \\
\hline 19 & SD NO. 1 BERATAN & 88 & 82,17 \\
\hline 20 & SD NO. 1 KENDRAN & 81 & 80,63 \\
\hline 21 & SD NO. 2 BANYUNING & 81 & 62,01 \\
\hline 22 & SD NO. 5 BANYUNING & 77 & 82,36 \\
\hline 23 & SD NO. 6 BANYUNING & 81 & 79,82 \\
\hline 24 & SD NO. 8 BANYUNING & 84 & 68,43 \\
\hline 25 & SD NO. 1 PENGLATAN & 86 & 90,00 \\
\hline 26 & SD NO. 2 PENGLATAN & 90 & 77,62 \\
\hline 27 & SD NO. 3 PENGLATAN & 84 & 75,16 \\
\hline 28 & SD NO. 1 ALASANGKER & 83 & 68,17 \\
\hline 29 & SD NO. 2 ALASANGKER & 78 & 61,55 \\
\hline 30 & SD NO. 3 ALASANGKER & 85 & 72,38 \\
\hline Mean Score & 83,80 & 77,16 \\
\hline & & & \\
\hline & & & \\
\hline & & & \\
\hline
\end{tabular}

Based on the analysis of the previous table, it is gained that teacher professional competence score is at 83.80 and being categorized as very high. Meanwhile, students' mean score on natural 
science subject is 77.16 , and being categorized as very high.

Figure 1. Teacher Professional Competence

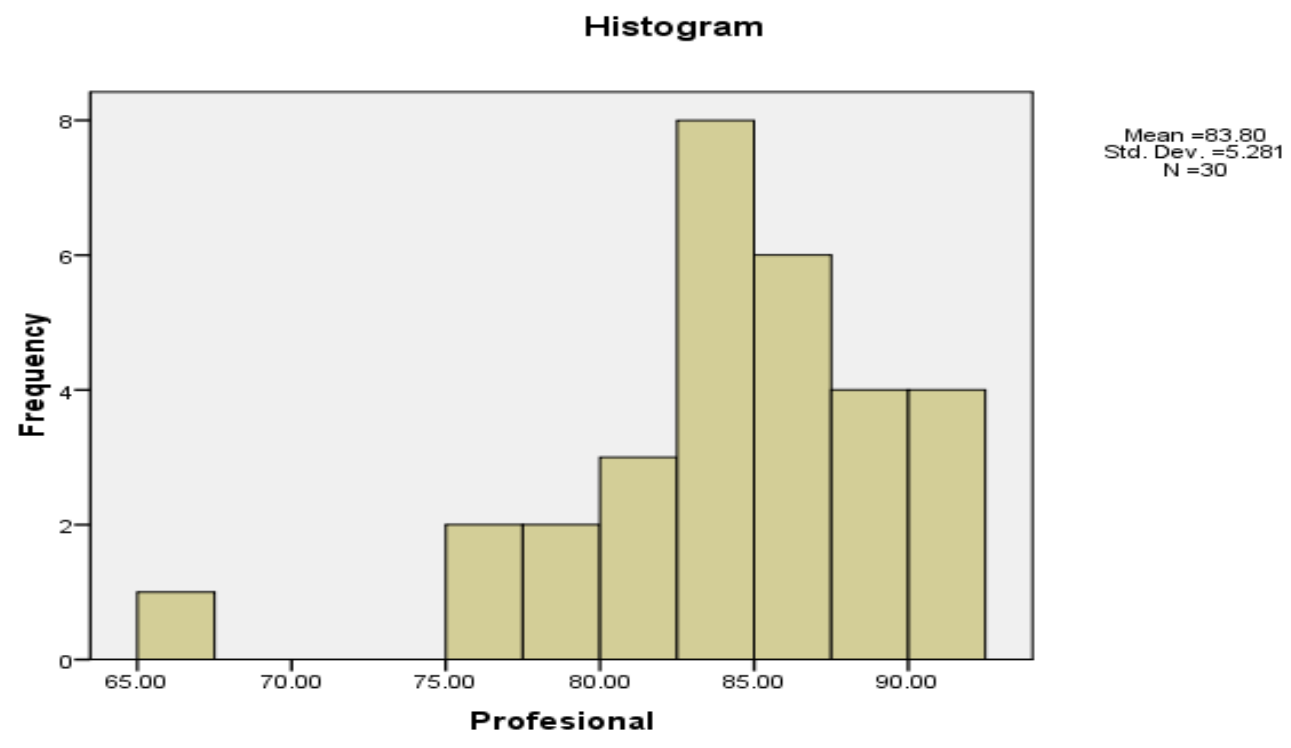

Accordingly, from those data, the researcher continues to calculate the correlation between teacher professional competence and students' achievement on natural science subject in academic year 2016/2017 by using SPSS 16. Based on the analysis, it is shown that the coefficient correlation is 0.506 . This means that there is a significant correlation between variables. In order to know the degree of correlation, the calculation is continued to t-test. From the $\mathrm{t}$-test, it is revealed that the $\mathrm{t}_{\text {count }}>\mathrm{t}_{\text {table }}$ $(3.103>2,048)$ with significance level at $5 \%$. Thereunto, in order to seek the effect of teacher professional competence toward students' learning achievement in national examination, the researcher persists to calculate the coefficient determination. The result of the calculation shows that the coefficient determination is at $0.2560(25.60 \%)$. In other words, teacher professional competence influences $25.60 \%$ students' achievement on natural science in national examination. Meanwhile, the other $74.40 \%$ of the achievement is influenced by other factors which are not interpreted in this study. These findings are supported by Pujasari and Nurdin (2012) who find out that students' achievement is influenced by teacher professional competence by $29.59 \%$.
To ensure that in natural science learning is meaningful, teachers are expected to emphasize the process compared to the outcomes and to involve students directly in learning. Teacher support is also essential to build understanding and confidence in natural science learning. Teachers support affect students in the way teachers define learning objectives clearly, prepare the materials, approach students and evaluate learning in the classroom (Richardson, 1996; Levitt, 2002).

Similarly, utilizing constructivist approach in natural science learning can also be done by teachers. They can start by exploring students' daily experience or encourage them to express ideas. In the end of the lesson, students are expected to build their critical thinking and creativity. Through this approach, teachers are able to see through possibilities and opportunities to explore students' potentiality. (Fitzgerald \& Smith, 2016).

Professional competence is about to master materials, concept, language structure, and meant to make teachers master basic and standard competence, develop their professionalism through the use of technology (Sikki et al., 2013). 


\section{CONCLUSION AND SUGGESTION}

Based on the data analysis, it is revealed that the coefficient correlation is at 0.506 and being classified as moderate, thus it can be stated that there is a high correlation between teacher professional competence and student achievement on natural science subject in the national exams. It is also noted that the t-test results in $t_{\text {count }}=3.103$ and it is higher than the $t_{\text {table }}=2.048$ with coefficient of determination at $0.256(25.60 \%)$.

Looking at the result of the study, the researcher suggests to all teachers to realize the importance of having four teacher competencies covering pedagogical competence, professional competence, social competence, and personal competence since it has been proven effective to improve students' learning achievement.

\section{REFERENCE}

Bertschy F., Kunzli,C.,\& Lehmann, M. (2013). Teachers' Competencies for the Implementation of Educational Offers in the Field of Education for Sustainable Development. Sustainability Journal. 5. 5067-5080. Doi:10.3390/su5125067

Dantes, N. (2012). Research Method. Yogyakarta: Andi Offset.

Drovnikov, A.S., Nikolaev,E.L., Afanasev,A.S., Ivanov,V.N., Petrova, T.N., Tenyukova,G.G., Maksimova,N.L., \& Povshednaya,F.V. (2016). Teachers Professional Competence Assessment Technology in Qualification Improvement Process. International Review of Management and Marketing. 6(1),111115.

Fitzgerald, A., Smith, K. (2016). Science that Matters: Exploring Science Learning and Teaching in Primary Schools. Australian Journal of Teacher Education, 41(4). dx.doi.org/10.14211/ajte.2016v31n4.4.

Hakim, A. (2015). Contribution of Competence Teacher (Pedagogical, Personality, Professional Competence and Social) On the Performance of Learning. The International Journal of Engineering and Science.4(2), 1-12

Ilanlou'1, M., \& Zand, M.. (2011). Professional Competencies of Teachers and the Qualitative Evaluation. Proceeding of
Social and Behavioral Science. 29, 11431150.

Koksal N. (2013). Competencies in Teacher Education: Preservice Teachers' Perceptions about Competencies and Their Attitudes. Academic Journal.8(6),270-276

Kordestani F.,Aghdam,N.S.G.,\& Daneshfar, A. (2014). The Study of Elementary School Teachers' Professional Competencies and Comparing it with International Standards. International Journal of Academic Research in Progressive Education and Development.3(4),180-184

Levitt, K.E. (2002). An Analysis of Elementary Teachers' Beliefs Regarding the Teaching and Learning of Science. Science Education, 86(1), 1-22.

Mudiono, A. (2016). Keprofesionalan Guru dalam Menghadapi Pendidikan di Era Global. Prosiding Seminar Nasional Jurusan KSDP-Prodi S1 PGSD UNM. 4350

Pujasari, Y., \& Nurdin. (2012). Pengaruh Kompetensi Profesional Guru Terhadap Keberhasilan Belajar Siswa. Jurnal Jurusan Administrasi Pendidikan FIP UPI

http://file.upi.edu/Direktori/FIP/JUR. AD MINISTRASI PENDIDIKAN/19790712 2005011-

NURDIN/JURNAL NURDIN.pdf .(2012).

Richardson, V. (1996). The Role of Attitudes and Beliefs in Learning to Teach. In. J. Sikula (ed.), Handbook of Research on Teacher Education. New York: McMillan pp. 102-119.

Sikki,E.A.A., Rahman,A.,Hamra,A., \& Noni,N. (2013). The Competence of Primary School English Teacher in Indonesia. Journal of Education and Practice. 11(4), 139-145.

Sugiharti, S. (2016). Multidimensi Kompetensi Profesionalisme Guru. Prosiding Seminar Nasional Jurusan KSDP-Prodi S1 PGSD UNM. 121-128.

Trilling, B. \& Fadel C. (2009). $21^{\text {st }}$ Century Skills: Learning for Life in Our Times. San Fransisco: Josey-Bass. 